PA3IHA T. I.,

здобувач кафедри

адміністративного права

(Запорізький національний університет)

\title{
УДК 342.9:346.543
}

DOI https://doi.org/10.32842/2078-3736-2019-5-2-13

\section{АДМІНІСТРАТИВНО-ПРАВОВІ ЗАСАДИ \\ ІНВЕСТИЦІЙНОЇ ДІЯЛЬНОСТІ В УКРАЇНІ}

У науковій публікації досліджуються адміністративно-правові засади інвестиційної діяльності в Україні. Здійснюється класифікація нормативно-правових актів, які регулюють питання інвестицій та інвестиційної діяльності, а також принципів такої діяльності. До адміністративно-правових засобів забезпечення позитивного інвестиційного клімату в Україні віднесено такі: норми Конституції України, міжнародні договори, ратифіковані Верховною Радою України, серед яких провідне місце посідає Угода про асоціацію між Україною та ЄС; відповідне національне законодавство (чинні закони України щодо розвитку, стимулювання, забезпечення та захисту інвестиційної діяльності, відповідні укази Президента та постанови Кабінету Міністрів України); відомчі нормативно-правові акти міністерств та інших органів публічної адміністрації, які деталізують законодавчі акти щодо порядку та засобів здійснення інвестиційної діяльності; акти судової гілки влади, серед яких провідне місце займають рішення Конституційного Суду України, висновки Верховного Суду та рішення касаційних судів, у яких визначаються уніфіковані підходи, правила щодо застосування норм матеріального та процесуального права у сфері інвестицій та інвестиційної діяльності.

До принципів здійснення інвестиційної діяльності віднесено такі: принципи верховенства права, законності, диспозитивності, публічності (гласності), свободи договору, свободи вибору форми та способу здійснення інвестиційної діяльності, неприпустимості позбавлення права власності (крім випадків, чітко передбачених Конституцією та законами), судового захисту порушених прав, справедливості, добросовісності та розумності.

Формулюється висновок про те, що є необхідність у прийнятті єдиного нормативно-правового акта, який буде регулювати питання інвестицій та інвестиційної діяльності в Україні.

Ключові слова: правові засади, принципи, інвестиції, інвестиційна діяльність, публічно-правові відносини, адміністративно-правове регулювання, систематизачія, міжнародні угоди, захист інвестииій.

In the scientific publication the administrative and legal principles of investment activity in Ukraine are investigated. Classification of legal acts regulating the issues of investment and investment activity is carried out, as well as the principles of such activity. The administrative and legal means of ensuring a positive investment climate in Ukraine include: the norms of the Constitution of Ukraine, international treaties ratified by the Verkhovna Rada of Ukraine, among which the Association Agreement between Ukraine and the EU occupies a leading position; relevant national legislation: current laws of Ukraine on development, stimulation, provision and protection of investment activity, relevant Decrees of the President and the Cabinet of Ministers of Ukraine; departmental regulatory acts of ministries and other public administration

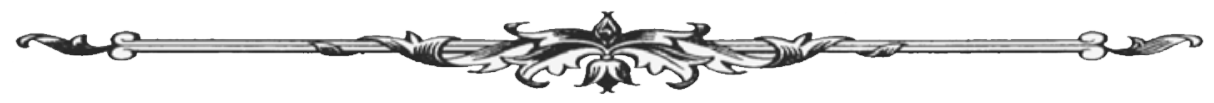


bodies detailing legislative acts on the procedure and means of carrying out investment activities; acts of the judicial branch of power, among which the leading place is held by the Constitutional Court of Ukraine, Conclusions (legal positions) of the Supreme Court, which define unified approaches, rules on the application of substantive and procedural law in the field of investment and investment activities.

The principles of investment activity include: the rule of law, legality, dispositiveness, publicity (transparency), freedom of contract, freedom to choose the form and method of investment activity, inadmissibility of deprivation of property rights (except in cases clearly stipulated by the Constitution and laws), judicial protection of violations rights, justice, integrity and reason.

The conclusion is formulated, that there is a need to adopt a single legal act that will regulate the issues of investment and investment activity in Ukraine.

Key words: legal principles, principles, investments, investment activity, public relations, administrative and legal regulation, systematization, international agreements, investment protection.

Вступ. Сучасний стан правового регулювання інвестиційної діяльності в Україні потребує суттєвого удосконалення, про що свідчить прийняття 20 вересня 2019 року Закону України «Про внесення змін до деяких законодавчих актів України щодо стимулювання інвестиційної діяльності в Україні». Значна кількість нормативно-правових актів, які регулюють окремі питання інвестицій та інвестиційної діяльності, не сприяє покращенню інвестиційного клімату в Україні. Іноземний інвестор має бути переконаний у безпечності своїх інвестицій в економіку України, у недоторканності придбаної власності, коштів на банківських рахунках та у своїй власній безпеці. Особливої актуальності питання правового забезпечення інвестиційної діяльності набуває в умовах продовження збройної агресії Російської Федерації на сході України та в контексті нових глобалізаційних викликів. Україна зробила свій геополітичний вибір, тому основна увага повинна приділятися дотриманню європейських стандартів і принципів інвестиційної діяльності. Враховуючи вищезазначене, дослідження адміністративно-правових засад інвестиційної діяльності в Україні має як теоретичне, так і практичне значення.

Адміністративно-правові засади здійснення різних видів економічної діяльності досліджуються в роботах фахівців у сфері адміністративного права, серед яких роботи О. Бандурки, В. Бевзенка, Н. Губерської, С. Гусарова, Р. Калюжного, Т. Коломоєць, В. Колпакова, А. Комзюка, О. Кузьменко, В. Курила, Д. Лук'янця, Д. Лученка, Р. Мельника, О. Миколенка, Н. Нижник, Д. Приймаченка, С. Стеценко, М. Тищенка, А. Школика та інших учених-адміністративістів. Серед останніх досліджень слід згадати роботи Д. Заброди «Адміністративно-правові засади: сутність та зміст категорії» [1], Ю. Світличної «Адміністративно-правові засади державного регулювання іноземного інвестування в Україні» [2], Г. Федорова «Адміністративно-правові засади іноземного інвестування в Україні» [3], С. Теленик «Адміністративно-правові основи скринінгу інвестицій в об'єкти критичної інфраструктури» [4], В. Князєва «Адміністративно-правові засади формування та реалізації інвестиційних відносин в Україні» [5], М. Бліхар «Адміністративно-правові форми та методи регулювання інвестиційної діяльності» [6] та «Правова природа інвестиційної діяльності: адміністративно-правове дослідження» [7] та інших відомих науковців.

Методологія дослідження грунтується на комплексному поєднанні філософських (діалектики та метафізики), загальнонаукових (прийомів логічного методу, системного та структурно-функціонального методів) та спеціально-юридичних методів дослідження, принципів об'єктивності та історизму.

Постановка завдання. Метою наукової публікації є дослідження адміністративно-правових засад інвестиційної діяльності в Україні із урахуванням останніх змін до національного законодавства України, сучасної юридичної практики та нових геополітичних викликів.

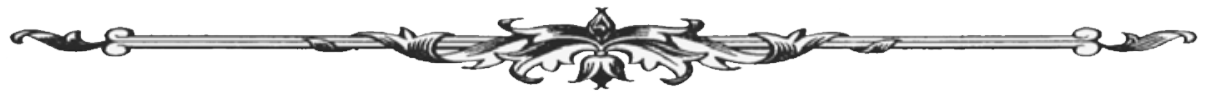


Результати дослідження. Адміністративно-правові засади інвестиційної діяльності $€$ тим правовим фундаментом, який дозволяє ефективно здійснювати відповідну юридичну практику. До них відносяться: міжнародно-правові акти, чинне національне законодавство, судова та адміністративна практика, а також принципи здійснення інвестиційної діяльності.

3 урахуванням вищезазначеного до адміністративно-правових засад інвестиційної діяльності в Україні доцільно віднести такі:

- норми Конституції України, які гарантують недоторканість особи та приватної власності, верховенство права, презумпцію невинуватості, свободу підприємницької діяльності;

- міжнародні договори, ратифіковані Верховною Радою України, серед яких провідне місце посідає Угода про асоціацію між Україною та ЄС, яку ратифіковано Законом України № 1678-VII від 16 вересня 2014 року [8];

- відповідне національне законодавство: чинні закони України щодо розвитку, стимулювання, забезпечення та захисту інвестицій та інвестиційної діяльності;

- відомчі нормативно-правові акти міністерств та інших органів публічної адміністрації, які деталізують законодавчі акти щодо порядку та засобів здійснення інвестиційної діяльності (накази міністерств та інших органів публічної адміністрації, які формують основний масив правових засобів адміністративно-правового регулювання інвестиційної діяльності);

- акти судової гілки влади, серед яких провідне місце займають Рішення Конституційного Суду України, Висновки Верховного Суду, рішення касаційних судів, в яких визначаються уніфіковані підходи, правила щодо застосування норм матеріального та процесуального права у сфері інвестицій та інвестиційної діяльності.

Першоджерелом багатосторонньої міжнародно-правової практики у сфері регулювання інвестиційних правовідносин стала Угода про Міжнародний валютний фонд (далі МВФ), що вступила в силу 27 грудня 1945 року. Вона поклала початок правовому регулюванню міжнародного руху капіталів і міжнародно-правовій співпраці у сфері іноземних інвестицій. Потім у межах таких міжнародних організацій, як Європейське економічне співтовариство і Організація економічного співробітництва і розвитку, було створено певний механізм регулювання транснаціонального руху капіталів, що сприяло вдосконаленню механізму правового регулювання іноземних інвестицій на багатосторонній основі. Масив нормативного матеріалу відповідної якості й кількості в сфері іноземних інвестицій говорить сам за себе. До 1998 року у світі було укладено близько 1500 міжнародних двосторонніх угод про взаємне заохочення й захист закордонних капіталовкладень за участю 170 країн. Діє також низка багатосторонніх договорів, покликаних регулювати іноземні інвестиції відповідно до міжнародних стандартів. Найцінніший арсенал міжнародних інвестиційних норм і правил знаходиться у двох універсальних багатосторонніх договорах - Вашингтонській конвенції 1965 року «Про порядок вирішення інвестиційних суперечок між державами й іноземними особами іншої держави» та Сеульскій конвенції 1985 року «Про організацію багатостороннього агентства по гарантіях інвестицій», а також у Договорі до Європейської Енергетичної Хартії [9].

До категорії міжнародних договорів, що регулюють міжнародні інвестиційні відносини, також належать такі: Генеральна угода про тарифи й торгівлю, угоди, що лежать в основі створення регіональних економічних союзів держав, зокрема Європейського Союзу.

Одним із договорів, суміжних із Генеральною угодою про тарифи й торгівлю, $є$ Угода 3 торговельних аспектів інвестиційних заходів (Agreement on Trade-Related Investment Measures), прийнята як складова частина пакету документів Світової організації торгівлі в 1994 р. Угода одночасно стосується міжнародної торгівлі та інвестиційної діяльності. Угода $з$ торговельних аспектів інвестиційних заходів - єдиний документ пакету СОТ, що має безпосереднє відношення до інвестиційної діяльності. Основними принципами вказаної угоди є зобов'язання членів Світової організації торгівлі дотримуватися щодо іноземних інвестицій принципу національного режиму і принципу заборони кількісних обмежень. Угода містить також перелік обмежень, неприпустимих щодо іноземних інвестицій.

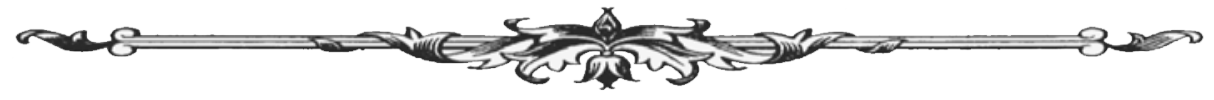


До міжнародних нормативно-правових актів, ратифікованих Верховною Радою України, які регламентують порядок здійснення інвестиційної діяльності, належать такі: Конвенція про захист прав інвестора від 28 березня 1997 року [10], Конвенція про порядок вирішення інвестиційних спорів між державами та іноземними особами, ратифікована Законом № 1547-III від 16 березня 2000 року [11], двосторонні угоди про сприяння та захист інвестицій (наприклад, Угода між урядом України та урядом Канади про сприяння та захист інвестицій від 24 жовтня 1994 року, ратифікована Україною 2 червня 2005 року, Угода між урядом України та урядом Держави Ізраїль про взаємне сприяння та захист інвестицій від 24 листопада 2010 року, ратифікована Україною 1 червня 2011 року [12] тощо).

Серед законів, які виступають правовою основою здійснення інвестиційної діяльності та забезпечення позитивного інвестиційного клімату в Україні, слід виділити такі закони України: «Про інвестиційну діяльність», «Про режим іноземного інвестування», «Про стимулювання інвестиційної діяльності у пріоритетних галузях економіки з метою створення нових робочих місць». Серед останніх - Закон України «Про внесення змін до деяких законодавчих актів України щодо стимулювання інвестиційної діяльності в Україні» від 20 вересня 2019 року № 132-IX.

Наприклад, Закон України «Про інвестиційну діяльність» від 18 вересня 1991 р. визначає загальні правові, економічні та соціальні умови інвестиційної діяльності на території України. Він спрямований на забезпечення рівного захисту прав, інтересів і майна суб'єктів інвестиційної діяльності незалежно від форм власності, а також на ефективне інвестування економіки України, розвитку міжнародного економічного співробітництва та інтеграції [13].

Закон України «Про режим іноземного інвестування» від 19 березня 1996 року № 93/96-ВР визначає особливості режиму іноземного інвестування на території України, виходячи з цілей, принципів і положень законодавства України. Згідно із ст. 3 Закону України «Про режим іноземного інвестування» іноземні інвестиції можуть здійснюватися у таких формах: часткової участі у підприємствах, що створюються спільно з українськими юридичними і фізичними особами, або придбання частки діючих підприємств; створення підприємств, що повністю належать іноземним інвесторам, філій та інших відокремлених підрозділів іноземних юридичних осіб або придбання у власність діючих підприємств повністю; придбання не забороненого законами України нерухомого чи рухомого майна, включаючи будинки, квартири, приміщення, обладнання, транспортні засоби та інші об’єкти власності, шляхом прямого одержання майна та майнових комплексів або у вигляді акцій, облігацій та інших цінних паперів; придбання самостійно чи за участю українських юридичних або фізичних осіб прав на користування землею та використання природних ресурсів на території України; придбання інших майнових прав; господарської (підприємницької) діяльності на основі угод про розподіл продукції; в інших формах, які не заборонені законами України, в тому числі без створення юридичної особи на підставі договорів із суб'єктами господарської діяльності України. Іноземні інвестиції можуть вкладатися в будь-які об'єкти, інвестування в які не заборонено законами України [14].

Закон України «Про стимулювання інвестиційної діяльності у пріоритетних галузях економіки з метою створення нових робочих місць» від 6 вересня 2012 року № 5205-VI визначає основи державної політики в інвестиційній сфері протягом 2013-2032 років щодо стимулювання залучення інвестицій у пріоритетні галузі економіки. Цей Закон спрямований на створення умов для активізації інвестиційної діяльності шляхом концентрації ресурсів держави на пріоритетних напрямах розвитку економіки 3 метою запровадження новітніх та енергозберігаючих технологій, створення нових робочих місць, розвитку регіонів [15].

Новелою національного законодавства у сфері забезпечення позитивного інвестиційного клімату є Закон України «Про внесення змін до деяких законодавчих актів України щодо стимулювання інвестиційної діяльності в Україні» від 20 вересня 2019 року № 132-IX [16].

У висновку на проєкт вказаного Закону Головного науково-експертного управління Верховної Ради України зазначено, що, згідно із пояснювальною запискою до проєкту, його розроблено з метою «поліпшення інвестиційного клімату України за окремими напрямами,

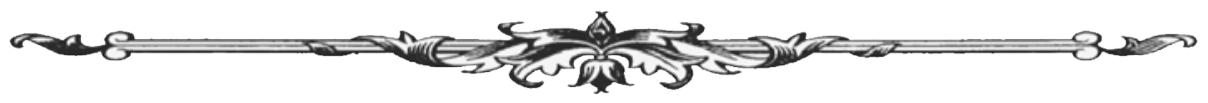


обраними внаслідок комплексної оцінки відповідності законодавства України кращим світовим практикам, описаним Групою Світового банку у методології рейтингу Doing Business». Для досягнення поставленої мети у проєкті пропонується внести відповідні зміни до Кодексу України про адміністративні правопорушення, Цивільного кодексу України, Земельного кодексу України, Господарського процесуального кодексу України, Кодексу України з процедур банкрутства та законів України «Про нотаріат», «Про забезпечення вимог кредиторів та реєстрацію обтяжень», «Про державну реєстрацію юридичних осіб, фізичних осіб-підприємців і громадських формувань», «Про державну реєстрацію речових прав на нерухоме майно та їх обтяжень» тощо. Наслідком прийняття проєкту, як зазначено у пояснювальній записці до нього, стане: «зниження кількості порушень прав міноритарних акціонерів; зниження вартості кредитних ресурсів; зменшення витрат, пов'язаних з будівництвом житлових та нежитлових об'єктів». Зокрема, вказаним законом передбачено: запровадження довірчої власності як способу забезпечення виконання договірних зобов'язань; скасування обов'язку сплати пайового внеску у розвиток інфраструктури населеного пункту, також скасовується обов'язковість проведення експертної грошової оцінки земельних ділянок приватної власності, які передаються у заставу, тощо [17].

Висновок містить низку зауважень до законопроєкту. Вкрай сумнівною, на думку експертів, видається пропозиція про запровадження права довірчої власності у запропонованому у проєкті вигляді. Для цього гл. 49 Цивільного кодексу України доповнюється новим $\S 8$, а також вносяться певні зміни як до інших положень ЦК України, Кодексу України 3 процедур банкрутства, так і до законів України «Про нотаріат», «Про державну реєстрацію прав на нерухоме майно та їх обтяжень», «Про забезпечення вимог кредиторів та реєстрацію обтяжень», «Про банки і банківську діяльність», «Про систему гарантування вкладів фізичних осіб» тощо. У цих змінах встановлюється, що право довірчої власності виникає на підставі договору між довірчим засновником та довірчим власником про встановлення довірчої власності (ч. 1 нової ст. 597-3 ЦК України). Довірчим засновником пропонується вважати боржника за основним зобов'язанням та/або іншу особу, яка передає своє майно у довірчу власність із метою забезпечення виконання зобов'язання боржника (ч. 2 нової ст. 597-3 ЦК України). Довірчим власником пропонується вважати кредитора за основним зобов'язанням (ч. 3 нової ст. 597-3 ЦК України).

Головне науково-експертне управління не підтримує вищевказану новелу з наступних міркувань. Насамперед, за своєю природою право довірчої власності $є$ не окремим різновидом права власності, як це пропонується визначити у проєкті (ч. 2 нової ст. 597-1 ЦК України), а має розглядатися як один із видів речових прав на чуже майно. Це пояснюється, зокрема, тим, що цивільне право не передбачає існування різновидів права власності з різними наборами повноважень декількох власників щодо одного об’єкта права власності, що відображено, зокрема, у ч. 1 ст. 316 ЦК України, згідно з якою правом власності є право особи на річ (майно), яке воно здійснює відповідно до закону за своєю волею, незалежно від волі інших осіб.

Зазнається, що більшість науковців у сфері юриспруденції, причому не тільки українських, дотримуються позиції про те, що рецепція довірчої власності як інституту системи англосаксонського (прецедентного) права у систему романо-германського (континентального) права є сумнівною, а ефективність від неї буде вкрай низькою. По-перше, в англо-американській системі право власності складається з одинадцяти елементів, куди входить право управління і право на доход. Це засновано на традиціях прецедентного права. По-друге, жоден з учасників довірчої власності не має всієї сукупності правомочностей власника, а володіє лише їхньою частиною. Тобто виявити одного власника у такому складному правовідношенні неможливо. У зв'язку з цим французький правознавець Р. Давід стверджував: «Юристи континентального права завжди будуть бачити інститут представництва там, де англійський або американський юрист бачить довірчу власність» [17].

Щодо внесення змін до законодавчих актів у сфері будівництва експерти зазначають, що враховуючи сучасний стан економіки України та неспроможність фінансування заходів,

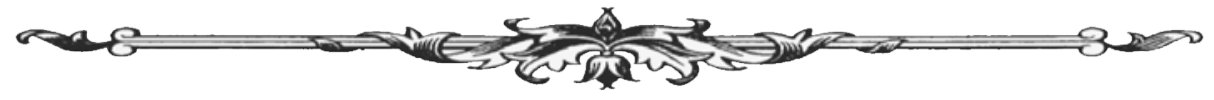


пов'язаних зі збереженням і розвитком інженерно-транспортної та соціальної інфраструктури населених пунктів виключно за рахунок державного фінансування або інших надходжень до місцевих бюджетів, кошти, отримані від пайової участі забудовників у розвитку інфраструктури населеного пункту, спрямовані на поліпшення «інвестиційного» клімату в Україні шляхом розвитку відповідної інфраструктури та є вагомим джерелом надходжень до місцевих бюджетів, які спрямовані саме на реалізацію таких заходів. У зв'язку $з$ цим скасування пайових внесків на розвиток інфраструктури може мати негативний соціально-економічний ефект, зокрема й внаслідок того, що збудовані об'єкти будівництва не будуть забезпечені відповідною інфраструктурою.

Тому більш доцільним було б не скасування пайового внеску замовника на розвиток інфраструктури населеного пункту, як це пропонується у проєкті, а оптимізація його розміру залежно від рівня розвитку такої інфраструктури та посилення контролю (зокрема, з боку замовника) за цільовим використанням отриманих місцевим бюджетом коштів саме на розвиток відповідної інфраструктури, а також більш чітке визначення природи пайового внеску як неподаткових надходжень до місцевих бюджетів [17].

Підсумовуючи, слід зазначити, що Закон України «Про внесення змін до деяких законодавчих актів України щодо стимулювання інвестиційної діяльності в Україні» від 20 вересня 2019 року № 132-ІХ демонструє значну кількість нормативно-правових актів, які регулюють окремі аспекти інвестицій та інвестиційної діяльності. Враховуючи вищезазначене, є потреба у проведенні систематизації нормативно-правових актів у сфері інвестиційної діяльності, створенні єдиного нормативно-правового акта, який буде зручним у користуванні, зрозумілим для інвестора, відповідати принципу правової визначеності, враховувати європейські стандарти та принципи у сфері інвестицій.

Серед відомчих нормативно-правових актів, які $є$ основою адміністративно-правового регулювання інвестиційної діяльності в Україні, слід виділити Наказ Міністерства економічного розвитку і торгівлі України від 25 жовтня 2016 року № 1785 «Про затвердження Порядку моніторингу стану розроблення (реалізації) державних інвестиційних проєктів» [18], Наказ Міністерства економічного розвитку і торгівлі України від 18 травня 2017 року № 723 «Про затвердження Положення про департамент залучення інвестицій» [19], Наказ Міністерства економічного розвитку і торгівлі України від 13 листопада 2012 року № 1279 «Про затвердження Методичних рекомендацій з розроблення інвестиційного проєкту, для реалізації якого може надаватися державна підтримка» [20].

До принципів здійснення інвестиційної діяльності слід віднести, по-перше, загально-правові принципи: верховенства права, поваги до прав і свобод людини, рівності всіх перед законом, законності, публічності (гласності), правової визначеності, тощо. Окрім загальних принципів, основою здійснення інвестиційної діяльності є спеціальні принципи, характерні для цивільного та господарського права, в межах яких здійснюється інвестиційна діяльність, а саме принципи: свободи договору, свободи вибору форми та способу здійснення інвестиційної діяльності, неприпустимості позбавлення права власності (крім випадків, чітко передбачених Конституцією та законами), судового захисту порушених прав, справедливості, добросовісності та розумності.

Висновки. Проведене дослідження адміністративно-правових засад здійснення інвестиційної діяльності в Україні дозволило сформулювати висновок про те, що наразі правовою основою інвестиційної діяльності в Україні є Конституція України, міжнародні нормативно-правові акти, ратифіковані Верховною Радою України, закони та підзаконні нормативно-правові акти, відповідна судова практика. До принципів здійснення інвестиційної діяльності слід віднести принципи верховенства права, законності, диспозитивності, публічності (гласності), свободи договору, свободи вибору форми та способу здійснення інвестиційної діяльності, неприпустимості позбавлення права власності (крім випадків, чітко передбачених Конституцією та законами), судового захисту порушених прав, справедливості, добросовісності та розумності.

Значна кількість нормативно-правових актів, які регулюють питання інвестицій та інвестиційної діяльності, не сприяє однозначному розумінню їхніх положень, дотри-

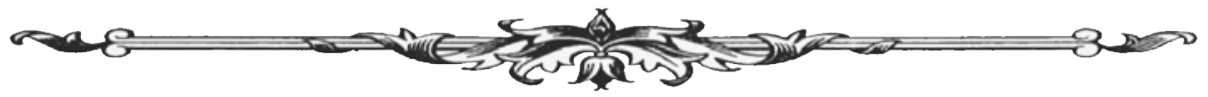


манню принципу правової визначеності, формуванню впевненості потенційного інвестора в захищеності своїх інвестицій, власності та особистій безпеці. 3 метою вдосконалення адміністративно-правових засад інвестиційної діяльності в Україні доцільно розробити та прийняти єдиний нормативно-правовий акт, який буде регулювати всі основні питання інвестиційної діяльності із урахуванням останніх глобалізаційних викликів та усталеної судової та адміністративної практики. Необхідність наукового узагальнення всього правового матеріалу, пов’язаного з інвестиціями та інвестиційною діяльністю, актуалізує необхідність подальшого дослідження цієї тематики.

\section{Список використаних джерел:}

1. Заброда Д.Г. Адміністративно-правові засади: сутність та зміст категорії. Aдміністративне право і проиес. 2013. № 2(4). С. 45-51.

2. Світлична Ю.О. Адміністративно-правові засади державного регулювання іноземного інвестування в Україні : автореф. дис. ... д-ра юрид. наук : 12.00 .07 - «Адміністративне право і процес; фінансове право; інформаційне право»; МВС України, Харківський нац. ун-т внутр. справ. Харків, 2017. 39 с.

3. Федоров Г.О. Адміністративно-правові засади іноземного інвестування в Україні. Вісник Харківського національного університету внутрішніх справ. 2019. № 2 (85). С. $78-86$.

4. Теленик С.Ф. Адміністративно-правові основи скринінгу інвестицій в об'єкти критичної інфраструктури. Адміністративне право і процесс. 2019. № 9. С. 135-141.

5. Князев В.С. Административно-правовые основы формирования и реализации инвестиционных отношений в Украине : автореф. дисс. ... канд. юрид. наук : 12.00 .07 «Адміністративне право і процес; фінансове право; інформаційне право»; Международный университет бизнеса и права. Херсон, 2011. 19 с.

6. Бліхар М.М. Адміністративно-правові форми та методи регулювання інвестиційної діяльності. Науковий вісник Львівського державного університету внутрішніх справ. 2013. № 3. C. 171-183.

7. Бліхар М.М. Правова природа інвестиційної діяльності: адміністративно-правове дослідження. Науковий вісник Ужгородського національного університету. 2015. Серія : Право. Вип. 31. Т. 2. С. 105-109.

8. Угода про асоціацію між Україною, з однієї сторони, та Європейським Союзом, Свропейським співтовариством з атомної енергії та їхніми державами-членами, з іншої сторони. URL: http://zakon3.rada.gov.ua/laws/show/984_011 (дата оновлення: 30.11.2015).

9. Гончарук Ю.П. Міжнародно-правові джерела регулювання іноземних інвестицій. Міністерство юстиції України : офіційний вебпортал. URL: https://minjust.gov.ua/m/str_23408.

10. Конвенція про захист прав інвестора від 28 березня 1997 р. Дата набрання чинності: 21.01.1999 p. URL: https://zakon.rada.gov.ua/laws/show/997_047.

11. Конвенція про порядок вирішення інвестиційних спорів між державами та іноземними особами : ратифікована Законом № 1547-III від 16 березня 2000 p. URL: https://zakon.rada.gov.ua/laws/show/995_060.

12. Міжнародні договори України. Украӥнська арбітражна асоціація. URL: http://arbitration.kiev.ua/uk-UA/Zakonodavstvo/Mizhnarodni-dogovory-Ukrainy.aspx?ID=166.

13. Про інвестиційну діяльність : Закон України від 18 вересня 1991 р. № 1560-ХII. URL: https://zakon.rada.gov.ua/laws/show/1560-12 (дата оновлення: 18.12.2017).

14. Про режим іноземного інвестування : Закон України від 19 березня 1996 р. № 93/96-BP. URL: https://zakon.rada.gov.ua/laws/show/93/96-вр (дата оновлення: 25.06.2016).

15. Про стимулювання інвестиційної діяльності у пріоритетних галузях економіки 3 метою створення нових робочих місць : Закон України від 6 вересня 2012 р. № 5205-VI. URL: https://zakon.rada.gov.ua/laws/show/5205-17 (дата оновлення: 01.01.2013).

16. Про внесення змін до деяких законодавчих актів України щодо стимулювання інвестиційної діяльності в Україні : Закон України від 20 вересня 2019 р. № 132-IX. URL: https://zakon.rada.gov.ua/laws/show/132-20 (дата оновлення: 17.10.2019).

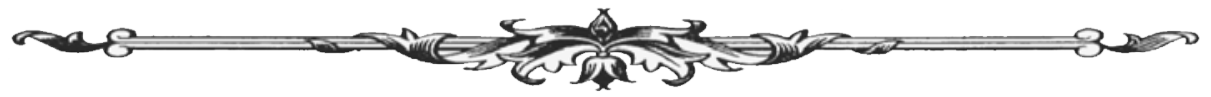


17. Висновок на проєкт Закону України «Про внесення змін до деяких законодавчих актів України щодо стимулювання інвестиційної діяльності в Україні» Головного науково-експертного управління Верховної Ради України. Верховна Рада України : офіційний вебпортал. URL: https://w1.c1.rada.gov.ua/pls/zweb2/webproc4_1?pf3511=66289.

18. Про затвердження Порядку моніторингу стану розроблення (реалізації) державних інвестиційних проєктів : Наказ Міністерства економічного розвитку і торгівлі України від 25 жовтня 2016 р. № 1785. URL: https://zakon.rada.gov.ua/laws/show/z1508-16 (дата оновлення: 13.12.2016).

19. Про затвердження Положення про департамент залучення інвестицій : Наказ Міністерства економічного розвитку і торгівлі України від 18 травня 2017 р. № 723. URL: https://zakon.rada.gov.ua/rada/show/v0723731-17 (дата оновлення: 12.12.2018).

20. Про затвердження Методичних рекомендацій з розроблення інвестиційного проєкту, для реалізації якого може надаватися державна підтримка : Наказ Міністерства економічного розвитку і торгівлі України від 13 листопада 2012 р. № 1279. URL: https://zakon.rada. gov.ua/rada/show/v1279731-12 (дата оновлення: 13.11.2012).

САЛАЕВ ТУРГУТ ГАДЖИ ОГЛЫ, аспирант отдела проблем развития национального законодательства (Институт законодательства Верховной Рады Украины)

УДК 342.95:343.359.3

DOI https://doi.org/10.32842/2078-3736-2019-5-2-14

\section{НЕКОТОРЫЕ ПРОБЛЕМЫ АДМИНИСТРАТИВНО-ПРАВОВОГО ОБЕСПЕЧЕНИЯ ИНФОРМАЦИОННОЙ БЕЗОПАСНОСТИ В ТАМОЖЕННОЙ СФЕРЕ}

Статья посвящена научному анализу состояния административно-правового механизма обеспечения информационной безопасности в таможенной сфере и выявлению имеющихся в нем проблем. Автором отмечено прежде всего на воздействии состояния имеющегося общегосударственного механизма административно-правового обеспечения информационной безопасности Украины на качество и эффективность формирования отраслевого механизма административно-правового обеспечения информационной безопасности в таможенной сфере. В дальнейшем исследованы отдельные структурные элементы механизма административно-правового обеспечения информационной безопасности в таможенной сфере и выявлены проблемы несовершенства нормативно-правового регулирования административно-правового обеспечения информационной безопасности непосредственно в таможенной сфере; функциональные проблемы описанного механизма и проблемы взаимодействия субъектов административно-правового обеспечения информационной безопасности непосредственно в таможенной сфере.

Среди недостатков нормативно-правового регулирования административно-правового обеспечения информационной безопасности в таможенной сфере автором акцентировано внимание на неконсолидированности административно-правовых норм по обеспечению информационной безопасности в таможенной сфере, несовершенстве и несогласованности основных понятий и катего-

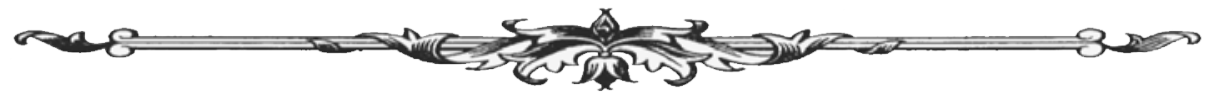

